удк 346.7

DOI https://doi.org/10.32837/pyuv.v1i3(28).330

\author{
А. О. Костюкова \\ orcid.org/0000-0002-0007-6270 \\ заступник директора \\ колунального підприєлства «Облконцертсервіс»
}

\title{
ЩОДО ОБ’СКТА ПРАВОВІДНОСИН У СФЕРІ ТЕАТРАЛЬНО-КОНЦЕРТНОЇ ДІЯЛЬНОСТІ
}

Постановка проблеми. Питання об'єктів правовідносин у сфері театрально-концертної діяльності є актуальним, передусім, через потребу чіткого визначення в національному законодавстві напрямів оптимізації управління культурною діяльністю та функціонування ринків послуг у цій сфері. Необхідним є також пристосування відповідного правового впливу до єдиних підходів щодо обсягу поняття об'єкта правовідносин у теоретико-правових дослідженнях. Ускладнює це питання відсутність єдності в розумінні поняття об'єкта правовідносин у господарсько-правовій літературі. Доробки представників цивілістичної думки $з$ даної тематики $є$ або занадто узагальненими (розглядаються правовідносини у цілому в галузі культури), або фрагментарними, не дозволяють отримати чітке уявлення щодо кола тих благ, із приводу яких суб'єкти театральної та концертної діяльності вчиняють певні дії, прагнучи досягти бажаних господарських інтересів.

Аналіз останніх досліджень і публікацій. Piвень розроблення проблем правового регулювання правовідносин щодо провадження театрально-концертної діяльності в Україні є недостатнім. Хоча загальнотеоретичні погляди на категорію «об'єкт правовідносин» відображені практично у всіх наукових працях із теорії права, але особливості об'єктного складу правовідносин у сфері шоу-бізнесу або в межах правової охорони інтелектуальної діяльності досліджували лише представники цивілістичної науки, зокрема O.М. Мельник, О.В. Жилінкова, О.О. Корбут та деякі ін. На жаль, зазначена проблематика не піддавалася господарсько-правовому аналізу, що утворюе прогалину в питаннях місця та ролі шоу-бізнесу на ринку культурних послуг у контексті державно-правового впливу.

Мета статті. Дослідити склад та юридичну природу об'єктів правовідносин щодо здійснення театрально-концертної діяльності за законодавством України.

Виклад основного матеріалу дослідження. Під об'єктом (об'єктами) правовідносин у теорії права зазвичай розуміють те, із приводу чого ті чи інші суб'єкти вступають у зв'язки з метою задоволення своїх певних інтересів і потреб [1, с. 193]; або інакше - те, із приводу чого виникає, існує саме правове відношення. При цьому досить розповсю- дженим є трактування об'єкта правовідносин як певних благ [2; 3, с. 127], якому протиставлявся підхід, згідно з яким тільки поведінка людей (дії чи утримання від дій) як зобов'язаних осіб повинна вважатися єдиним об'єктом правових відносин [4, с. 129].

Виходячи з потреб практики людської діяльності, можна відзначити більшу привабливість плюралістичних теоретико-правових концепцій, що вказують на множинність об'єкта правовідносин, адже об'єкти правовідносин настільки різноманітні, наскільки різноманітні правовідносини, що регулюються правом [5, с. 502]. При цьому відповідні об'єкти можуть бути зведені у групи, що об'єднують в основному однорідні за зовнішніми властивостями об'єкти правових відносин.

Багато представників господарсько-правової науки поділяють плюралістичний погляд на категорію об'єкта правовідносин, вказуючи при цьому, що «об'єкти господарського правовідношення є засобами здійснення господарського інтересу» [6, с. 72]. До них відносяться: речі, в тому числі гроші й цінні папери; дії зобов'язаних суб'єктів; власне діяльність господарюючого суб'єкта; нематеріальні блага, які використовуються під час здійснення господарської діяльності (фірмове найменування, товарний знак, комерційна таємниця тощо).

Позиція прихильників моністичного підходу грунтується на погляді про те, що об'єктом правовідносин можуть бути тільки вчинки, діяння суб'єктів, їхня поведінка, тобто фактичні суспільні відносини, оскільки тільки вони здатні реагувати на дію права, на вплив правовідносин [6, с. 15]. О.П. Подцерковний наполягає на тому, що визначення поняття об'єкта правовідносин саме через поведінку їхніх суб'єктів, діяльність останніх, є більш організаційно виправданим, адже передбачає творчий та вольовий характер суспільних відносин. Мотивація, активність і здатність до сприйняття організаційного впливу, як слушно вказує науковець, цілком зумовлює об'єктну основу людської поведінки [7, с. 189].

Таким чином, підкреслюється організаційно-правовий аспект господарських відносин, які визначають та упорядковують (об'єктивують) організаційно-управлінську та іншу фактичну поведінку учасників цих відносин - зобов'язану та 
управнену сторони. Це виводить аналіз за межі суто цивілістичного погляду, дозволяючи сприйняти об'єкт правовідносин не тільки і не стільки в «опредмеченому» (уречевленому) вигляді, скільки через призму людської діяльності, зумовленої певною сферою економічних зв'язків.

Отже, об'єкти правовідносин у сфері театрально-концертної діяльності мають бути розглянуті в контексті поєднання майнового та організаційного аспекту останньої. Якщо майнові елементи такої діяльності у своїй більшості перекликаються із цивільними правовідносинами, то організаційні елементи ведення театрального та концертного бізнесу характеризують цей вид економічної діяльності виключно в господарсько-правовій площині, позаяк пов'язані з публічними та управлінськими вимогами і правилами, які виходять за межі приватного права. При цьому організаційний аспект театрально-концертної діяльності має як внутрішній, так і зовнішній вияв. Наприклад, робота з організації концертних виступів певного суб'єкта театрально-концертної діяльності сполучена з вирішенням великої кількості завдань щодо пошуку майданчика для виступів, бронювання готелю для музикантів, забезпечення концерту відеотрансляцією, світлотехнікою, охороною тощо. У зв'язку із цим відповідний суб’єкт господарювання - організатор - перебуває у чисельних зв'язках організаційного характеру з іншими господарськими утвореннями, державними органами та недержавними організаціями. Таким чином, об’єкти правовідносин у сфері театрально-концертної діяльності мають як матеріальний, так і нематеріальний характер, адже самі ці правовідносини за своєю суттю є як майновими, так $і$ немайновими (організаційними).

Матеріальні об'єкти, якими є предмети матеріального світу, характерні головним чином для господарсько-майнових правовідносин, пов'язаних із використанням відповідного майна для здійснення діяльності у сфері театрально-концертного бізнесу. Серед великої кількості таких предметів позначимо: цілісні майнові комплекси театрально-видовищних, клубних закладів, будівлі, стаціонарні та пересувні споруди (наприклад, відкриті сцени, амфітеатри), колекції сценічного одягу, сценічне устаткування (в т.ч. поворотні механізми, завіси, світлове обладнання), грим та іншу бутафорію, музичні інструменти, різноманітний реквізит та багато інших.

Але об'єктами правовідносин у сфері театрально-концертної діяльності переважно є нематеріальні об'єкти, до яких належать: послуги; результати інтелектуальної, творчої діяльності; майнові та особисті немайнові права.

У правовому розумінні театральні та концертні послуги передбачають діяльність відповідних культурних закладів, організацій, колективів, окремих осіб, що виконується для задоволення культурно-духовних потреб клієнтів, тобто споживачів цих послуг. При цьому у випадку незадоволення (неповного задоволення) таких потреб клієнта внаслідок споживання відповідних послуг (наприклад, відвідування концертного шоу, що не сподобалось глядачу), він не вправі пред'явити претензії стосовно того, чи були надані послуги. Безумовно, що в цьому випадку театральні та концертні послуги мають містити в собі основні риси (ознаки), зокрема і особливо - персональне надання послуги виконавцем, без перекладання цього обов'язку на іншого суб'єкта господарських правовідносин (якщо інше не допускається договором про надання послуги).

Також до послуг як об’єкта правовідносин із приводу ведення театральної та концертної діяльності, безумовно, слід віднести комерційне посередництво. При цьому у сфері шоу-бізнесу комерційне посередництво реалізується саме через агентські послуги, що надаються продюсерами, імпресаріо, антрепренерами і т.п. агентами чи відповідними організаціями, які виконують в інтересах своїх клієнтів (артистів, сценаристів та ін.) дії з оформлення їхніх відносин із театрами, концертними організаціями, клубами, радіостанціями і т. ін. із приводу організації та проведення різноманітних театральних, концертних, гастрольних, фестивальних заходів. Як вірно відзначає Є.О. Суханов, такі агентські дії одночасно носять як юридичний, так i фактичний характер. Перші прямо випливають із правовідносин між агентом та принципалом та мають на меті продаж виконавських талантів, творчих робіт принципала третім особам за відповідними угодами. Фактичні ж дії передбачають, наприклад, проведення агентом рекламної кампанії, інших маркетингових заходів із вивчення та освоєння ринку, що не створює правовідносин принципала із третіми особами [8].

Посередницька (агентська) діяльність у культурно-творчій сфері за своїм економічним змістом є господарською операцією з надання послуг, a їі комерційний характер полягає в задоволенні не тільки матеріальних потреб принципала, але i власних економічних інтересів агента.

Отже, агентські послуги як об'єкт господарсько-правових відносин у сфері театрально-концертної діяльності являють собою сприяння, допомогу у встановленні певних зв'язків між суб'єктами таких відносин, сприяння укладенню угод між сторонами з метою організації концертів, спектаклів, шоу-вистав, іншої творчої діяльності та з метою отримання економічного результату.

Звернемо увагу на те, що дії учасників відносин із надання послуг у сфері театрального та концертного бізнесу носять переважно організаційно-господарський характер. Це пов'язано, передусім, із поведінкою задіяних у цій сфері суб’єктів, 
зумовленою запитом суспільства на отримання певного культурно-розважального продукту та необхідністю забезпечити цей запит надавачами послуг. Більше того, організаційний аспект проявляється в необхідності додержання сторонами досліджуваних відносин законодавчих вимог щодо захисту суспільної моралі [9, ст. ст. 3,4$]$, забезпечення застосування державної мови під час проведення театральних вистав та інших заходів у сфері культури і мистецтв [10, ст. 23], обмежень під час проведення гастрольних заходів [11, ст.ст. $3,3^{1}$ ], виконання завдань безпекового, просвітницького, дозвільного характеру тощо.

Однак не всі з наведених вимог регламентовані на законодавчому рівні. Тому з господарсько-правового погляду, враховуючи особливості об'єктного складу досліджуваних відносин, видається важливим упорядкування їхньої організаційної складової частини, адже саме завдяки організаційно-правовій вмотивованості сторін (суб'єктів) ними здійснюються свідомі, вольові акти поведінки, що відповідають приписам законодавства щодо забезпечення інтересів (естетичних, розважальних, мовних, безпекових та ін.) відповідних учасників театрально-концертних правовідносин, досягнення ними тих результатів (благ), які вони прагнуть отримати. Тому, на наш погляд, законодавцю слід посилити регулятивний вплив на поведінкову складову частину суб'єктів театрально-концертної діяльності, особливо (але не тільки) в сенсі якості фактичних дій організаторів відповідних заходів із надання послуг споживачам (глядачам, відвідувачам), оцінювання рівня забезпечення суспільного інтересу в процесі підготовки, демонстрації та «споживання» театрально-концертної продукції. Чітка організація господарської діяльності, яка проявляється саме через упорядкування поведінки управненої та зобов'язаної сторін правовідносин, створює необхідні умови для іï̈ здійснення.

Кажучи про театральні та концертні послуги як об’єкт досліджуваних правовідносин, відзначимо також, що до їі специфічних ознак (як-от: фактична і юридична одночасність їх надання та споживання; безпосередній зв'язок із надавачем послуг, конкретним виконавцем фактичних і юридичних дій; їхня матеріальна невідчутність, тобто відсутність уречевленого результату; одиничність форм їх створення та відтворення, а також доступність для масового споживання; направленість на задоволення духовних, освітньо-естетичних, розважальних та інших культурних потреб; їх переважно творчій характер) слід додати її організаційно-господарський характер (складову частину), що невід’ємно супроводжує та упорядковує творчу діяльність, маючи основною метою забезпечення суспільного інтересу під час споживання театрально-концертного продукту.
У свою чергу, творча діяльність також $\mathrm{\epsilon}$ об’єктом господарських правовідносин у сфері театрального та концертного бізнесу. Згідно із ч. 2 ст. 154 ГК України до відносин, пов'язаних із використанням у господарській діяльності прав інтелектуальної власності, застосовуються положення ЦК України з урахуванням особливостей, передбачених ГК та іншими законами України. У відповідності з положеннями статей 199 і 418 ЦК України право фізичної або юридичної особи на результати інтелектуальної, творчої діяльності визнається особливою категорією суб'єктивних цивільних прав. Вони мають абсолютний характер і традиційно іменуються виключними правами.

Варто відзначити, що поняття «творча діяльність» більш широке, ніж «інтелектуальна діяльність», позаяк будь-які результати інтелектуальної діяльності є результатами творчої, але тільки ті результати творчої діяльності стають об'єктами правової охорони, які відповідають встановленим вимогам закону. Останні і визнаються результатами (продуктами) інтелектуальної діяльності. Результатами інтелектуальної (творчої) діяльності є твори науки, літератури, мистецтва тощо. Для визнання їх об'єктами правовідносин вони повинні бути втілені у відповідну об'єктивну форму, достатню для їх сприйняття іншими особами. Сам же процес створення відповідних творів та інших результатів творчої діяльності залишається поза межами правового регулювання.

На відміну від речей, продукти творчої діяльності є об’єктами (благами) нематеріального характеру, хоча матеріальні носії продуктів названої діяльності (книги, магнітні плівки, лазерні диски тощо) є речами і можуть виступати об'єктами права власності та інших майнових прав. Відповідне майнове право на матеріальний носій не дає власнику права на результат творчої діяльності, яке, включаючи право авторства, завжди зберігається за його творцем.

Загалом до результатів творчої діяльності як об’єктів правовідносин у сфері театрально-концертної діяльності (на підставі аналізу глав 36-37 ЦК України) варто відносити: літературні, драматичні, музичні, аудіовізуальні, а також художні та фотографічні твори; їх сценічне виконання, в т.ч. із об'єднанням інших продуктів творчості та їх обробленням або без нього; створення відеограм, фонограм. Перші з наведених продуктів належать до об'єктів авторських прав, останні до об'єктів суміжних прав.

Господарсько-правова характеристика цих об'єктів у цілому співпадає із цивілістичним підходом до кваліфікації складу майнових правовідносин, тому не будемо зупинятися на їх дослідженні в межах цієї роботи. Звернемо увагу лише на деякі аспекти, пов'язані із суміжними правами окремих суб’єктів театрально-концертної діяльності. 
Найчастіше саме виконання музичних, драматичних та інших творів стає об'єктом правовідносин, зумовлених наданням театрально-концертних послуг. Законодавець відносить публічне виконання до об'єкта суміжних прав [12, п. «а» ст. 35]. Однак, як видається, сценічне виконання має розглядатися як об'єкт подвійного значення: у широкому сенсі - це об'єкт суміжного права, оскільки підпорядковується (походить, залежить від, грунтується на) іншим об'єктам авторських прав, але у вузькому сенсі сценічне виконання $\mathrm{e}$ продуктом творчої діяльності конкретного виконавця, у зв'язку із чим може виступати об'єктом авторських прав виконавця.

Зазначене бачення підтверджується і позицією деяких інших дослідників. Наприклад, О. Морозова зазначає, що виконання є особливим способом подання твору, міцно пов'язаним із творчим процесом [13, с. 7]. Д. Липцик вказує, що, на відміну від твору, виконання являє собою його творчу інтерпретацію, що подекуди має значно вищу цінність, аніж сам твір [14, с. 323].

3 урахуванням наведеного видається вірним правове розуміння виконання твору як акту інтерпретаційної творчості виконавця, а не простого механічного, тобто бездуховного, відтворення виконавцем (актором, музикантом тощо) того чи іншого твору. Утім, відзначимо, що інші науково-юридичні джерела висловлюють у цьому питанні інший погляд (див., напр. [15, с. $493 ; 16$, с. 54$]$.

Питання майнових прав як об'єктів правовідносин у юридичній науці є доволі дискусійним. Воно ускладнюється існуванням у правовому обороті виключних прав, які за своєю природою належать до майнових і значною мірою притаманні саме відносинам у сфері культурно-творчої діяльності.

Майнові права автора, що визначені в законі (зокрема, гл. 36 ЦК України), мають універсальне значення. Вони належать будь-якому автору незалежно від сфери його творчої роботи. Не є виключенням і сфера театрально-концертної діяльності людини чи колективу людей. Особа (особи), яка створила драматичний, музичний та інший твір, набуває право на власне використання свого твору, а також на надання дозволу або на заборону використання цього твору іншими особами. Основним серед майнових прав автора чи іншої особи, яка володіє авторськими правами, є право на авторську винагороду за кожен спосіб використання його твору. Таким чином, через майнові права реалізуються матеріально-фінансові інтереси автора (колективу авторів чи інших осіб, що володіють авторськими правами).

Майнові права виконавця, виробника відеограми, фонограми, організації мовлення, як володільців суміжних прав на відповідний об'єкт творчої діяльності (ст. ст. 453, 454 ЦК України), це виключні права на особисте використання та надання дозволу/заборону використання цих об'єктів іншими особами, а також на отримання матеріальної винагороди за кожен спосіб їх використання.

Законом наводяться лише основні дії та основні майнові права авторів та інших володільців прав інтелектуальної власності, тобто їх перелік не є вичерпним. Наприклад, у ЦК України прямо не встановлено право на розміщення об'єктів авторського чи суміжного права в цифровому (Iнтернет) середовищі. Однак таке право є частиною права на відтворення твору в будь-якій спосіб та формі (п. 1 ч. 1 ст. 441) або доведення виконання для загального відому публіки (п. 1 ч. 1 ст. 453).

Принциповими відмінностями між майновими та особистими немайновими правами автора є їхня різна часова дія та їхня абсолютна чи відносна приналежність автору. Якщо перші можуть бути передані іншим особам (наприклад, на підставі договору), то право авторства як основне особисте немайнове право $є$ невідчужуваним, тобто таким, що не може бути передано іншим особам [12, ч. 2 ст. 14] навіть після передачі виключних немайнових прав на використання твору. Крім того, майнові права мають обмежений термін дії, тоді як особисті немайнові права безстрокові.

Слід відзначити, що поряд із майновими правами особисті немайнові права на об'єкти суміжних прав мають тільки виконавці, на відміну від усіх інших суб'єктів суміжних прав, які наділяються лише майновими правами. Уперше особисті немайнові права виконавців були задекларовані лише в 1996 році, коли виконавець наділявся правом заперечувати проти будь-якого перекручування, спотворення чи іншої суттєвої зміни своїх виконань, що може завдати шкоди його честі і репутації [17, п. 1 ст. 5]. Національне законодавство України наділяє виконавця й іншими особистими немайновими правами [12, ч. 1 ст. 38].

Таким чином, виконавцю стосовно власного виконання (творчої інтерпретації) належать, по суті, ті ж самі (чи дуже схожі) особисті немайнові та майнові права, що й автору по відношенню до свого твору.

Щодо виробників фонограм, відеограм і організацій мовлення, то законодавець наділив їх правами на зазначення свого імені (назви) на кожному носії запису або його упаковці поряд із зазначенням авторів, виконавців і назв творів, а також на згадування свого імені (назви) у зв'язку з використанням фонограми (відеограми), записом, відтворенням, розповсюдженням передачі (програми) і публічним повторним сповіщенням її іншою організацією мовлення (т.зв. право на ім'я (назву) [12, ч.ч. 2,3 ст. 38]. Звичайно, що це не можна прирівнювати до особистих немайнових прав виконавця, однак право на ім'я (назву), безумовно, індивідуалізує відповідну особу (організацію), 
певною мірою позначаючи автора представленого продукту у сфері культурно-розважальних та інших подібних послуг, що сприяє не тільки правовій охороні, але і комерційному застосуванню майнових прав цих суб’єктів у чисельних господарських відносинах.

Висновки та перспективи подальших досліджень. Коло об'єктів правовідносин у сфері театрально-концертної діяльності за своїм змістом, юридичними властивостями, способами створення, індивідуалізації, використання тощо є дуже широким та нерівномірним як із сутнісного, так і з вартісного погляду. Складність та неоднозначність у розумінні їхньї правової природи походить від множинності правовідносин, що формуються в суспільстві, та викликає проблеми щодо їх чіткого розмежування, управлінського впливу і захисту як на практиці, так і в теоретико-правовій площині.

Утім, усі вони активно використовуються з комерційною метою на ринку театрально-концертних послуг, що формується індустрією відпочинку та розваг, інтелектуально-духовною сферою суспільства. Тому, будучи предметами використання їх творцями у власній господарській діяльності або продажу чи тимчасової передачі іншим особам для одержання постійних доходів, внесення до статутних капіталів господарюючих суб'єктів тощо, об'єкти відносин у досліджуваному секторі належать до сфери господарсько-правового регулювання.

Iз погляду використання в театрально-концертній діяльності об'єкти правовідносин не є однорідними. В узагальненому вигляді їх варто поділяти на: 1) матеріальні об'єкти (рухоме та нерухоме майно театрів, клубів, інших закладів, організацій, колективів) та 2) нематеріальні об'єкти: а) послуги, у т.ч. агентські; б) результати творчої діяльності (драматичні, музичні, аудіовізуальні та інші твори; їх сценічне виконання (в комплексному поєднанні, з обробкою або без неї); створення відеограм, фонограм; програми (передачі) організацій мовлення); в) майнові та г) особисті немайнові права. Останні дві підгрупи, у свою чергу, доречно диференціювати на ті, що належать: авторам, виконавцям, виробникам фонограм, відеограм, програм (передач) мовлення.

Одним із найсуттєвіших об'єктів досліджуваних правовідносин варто визнавати дії їх учасників із надання послуг у сфері театрального та концертного бізнесу, які носять організаційно-господарський характер. Це зумовлено запитом суспільства на отримання певного культурно-розважального продукту та необхідністю забезпечити цей запит надавачами послуг. Організаційний аспект проявляється також у необхідності додержання учасниками цих правовідносин низки законодавчих публічних вимог щодо належної поведінки (дій), спрямованої на виконання завдань культурного, просвітницького, дозвільного, мовного, безпекового та іншого характеру. Вказане має на меті узгодження приватних та публічних інтересів у процесі вироблення та споживання результатів (благ) театральноконцертної діяльності, на досягнення яких орієнтована остання.

Серед багатьох дискусійних питань із порушеної проблематики, зокрема, можна вказати на потребу подальшого дослідження питань подвійного характеру публічного виконання творів у якості об’єкта прав інтелектуальної власності, а також ролі особистих немайнових прав для успішності господарської діяльності.

\section{Jimepamypa}

1. Загальна теорія держави і права : навч. посіб. / А.М. Колодій, В.В. Копєйчиков, С.Л. Лисенков та ін. ; за ред. В.В. Копєйчикова. Київ : Юрінком Інтер, 2000. $320 \mathrm{c}$.

2. Скакун О.Ф. Теорія держави і права : підручник. Харків : Консум, 2001. 656 c. URL : http://politics.ellib. org.ua/pages-1687.html.

3. Кельман М.С. Загальна теорія права (з схемами, кроссвордами, тестами) : підручник. Київ : Кондор, $2002.353 \mathrm{c}$

4. Иоффе О.С. Избранные труды: В 4 т. Т. I: Правоотношение по советскому гражданскому праву. Ответственность по советскому гражданскому праву. Санкт-Петербург : Юрид. центр Пресс, 2003. 574 с.

5. Теорія держави і права. Академічний курс : підручник / за ред. О.В. Зайчука, Н.М. Оніщенко. Київ : Юрінком Інтер. 2006. $688 \mathrm{c}$.

6. Віхров О.П. Організаційно-господарські правовідносини : автореф. дис...доктора юрид. наук за спец. 12.00.04 «Господарське право; господарсько-процесуальне право» ; НАН України. Ін-т економіко-правових досліджень. Донецьк, 2009. 37 с.

7. Подцерковный О.П. Денежные обязательства и расчетные правоотношения в Украине. Одесса : «Студия «Негоциант», 2005. 308 c.

8. Гражданское право: В 2 т. Том II. Полутом 2 : учебник / Отв. ред. проф. Е.А. Суханов. 2-е изд., перераб. и доп. / В.В. Витрянский, В.С. Ем, Н.В. Козлова и др. Москва : Изд-во БЕК, 2000. URL : https://studfiles.net/preview/6702169/page:56/.

9. Про захист суспільної моралі : Закон України від 20.11.2003 р. № 1296-IV). Відомості Верх. Ради України. 2004. № 14. Ст. 192.

10. Про забезпечення функціонування української мови як державної : Закон України від 25.04.2019 р. № 2704-VIII. Голос України від 16.05.2019. URL : http://www.golos.com.ua/article/317062.

11. Про гастрольні заходи в Україні : Закон України від 10.07.2003 р. №1115-IV. Відомості Верховної Ради України. 2003. № 32. Ст. 1686.

12. Про авторське право і суміжні права : Закон України від 23.12.1993 р. (в ред. Закону від 11.07.2001 р. № 2627-III). Відомості Верховної Ради України. 2001. № 43. Ст. 214.

13. Морозова О.М. Право інтелектуальної власності на виконання : автореф. дис. на здобуття наук. ступеня канд. юрид. наук : спец. 12.00.03 «Цивільне право і цивільний процес; сімейне право; міжнародне право». Київ, 2013. 20 с. 
14. Липцик Д. Авторское право и смежные права. Москва : Ладомир, Изд-во ЮНЕСКО, 2002.794 с.

15. Гражданский кодекс Украины : Научно-практический комментарий / Е.О.Харитонов, И.Н. Кучеренко, Е.И. Харитонова и др. / Под ред. Е.О. Харитонова, Н.Ю. Голубевой. изд. 6-е, с изм. и доп. Харьков : 000 «Одиссей», 2009. 1280 с.

16. Корбут 0.О. Непоіменовані договори у сфері шоу-бізнесу : дис. ... канд. юрид. наук за спец. 12.00.03 «Цивільне право і цивільний процес; сімейне право; міжнародне приватне право» ; НАПрН України, НДІ приват.права і підпр-ва ім. ак. Ф.Г. Бурчака. Київ, 2014. 263 c.

17. Договір Всесвітньої організації інтелектуальної власності по виконанню і фонограмам (м. Женева, 20.12.1996 р.). URL : https://wipolex.wipo.int/ru/ text/295480.

\section{Анотація}

Костюкова $A$. O. Щодо об'єкта правовідносин у сфері театрально-концертної діяльності. - Стаття.

Стаття присвячена дослідженню кола та змісту об'єкту правовідносин у такому секторі господарювання, як театральна і концертна діяльність, його місця $і$ ролі у творчо-виробничому середовищі, а також на ринку відповідних культурних послуг.

Об'єкти правовідносин у сфері театрально-концертної діяльності мають бути розглянуті в контексті поєднання майнового та організаційного аспекту останньої. Якщо майнові елементи такої діяльності переважно пов'язані із цивільними правовідносинами, то організаційні елементи ведення театрального та концертного бізнесу характеризують цей вид економічної діяльності виключно в господарсько-правовій площині. Адже вони пов'язані з публічними та управлінськими вимогами і правилами закону, які виходять за межі приватного права.

Організаційно-господарський погляд на об'єкти театрально-концертних послуг пов'язаний із запитом суспільства на досягнення культурних, просвітницьких, дозвільних, мовних, безпекових та інших результатів. Це зумовлює потребу узгодження приватних та публічних інтересів у процесі правового регулювання порядку вироблення та споживання результатів (благ) театрально-концертної діяльності.

Iз погляду використання в театрально-концертній діяльності об'єкти правовідносин варто поділяти на: 1) матеріальні об'єкти (рухоме та нерухоме майно театрів, клубів, інших закладів, організацій, колективів) та 2) нематеріальні об'єкти: а) послуги, в т.ч. агентські; б) результати творчої діяльності (драматичні, музичні, аудіовізуальні та інші твори; їх сценічне виконання (в комплексному поєднанні, з обробленням або без нього); створення відеограм, фонограм; програми (передачі) організацій мовлення); в) майнові та г) особисті немайнові права. Останні дві підгрупи належать: авто- рам, виконавцям, виробникам фонограм, відеограм, програм (передач) мовлення. До них належать: послуги; результати інтелектуальної, творчої діяльності; майнові та особисті немайнові права. Ці об'єкти переважно мають нематеріальний характер.

Ключові слова: театральна діяльність, концертна діяльність, театральні та концертні послуги, об'єкт правовідносин, матеріальні та нематеріальні об'єкти.

\section{Summary}

Kostyukova $A$. $O$. Concerning the object of legal relations in the sphere of theatrical and concert activity. Article.

This article is dedicated to research of area and content of object of legal relationships in such sector of menage as theatrical and concert activity to his place and role in a creatively-productive environment and also at the market of corresponding cultural services.

The objects of legal relationships in the field of theatrically-concert activity should be considered in the context of combination of property and organizational aspect of the last. If property elements of such activity mainly related to civil legal relationships, then the organizational elements of conduct of theatrical and concert business characterize this type of economic activity exceptionally in a business law plane. In fact they are related to the public and administrative requirements and rules of law, that standing out of private low.

An Organizationally-economical glance on the objects of theatrically-concert services is related to the request of society for the achievement of cultural, educational, permissive, linguistic, safety and other results. It stipulates the necessity of concordance of private and public interests in the process of the legal adjusting of order of making and consuming of results (welfare) of theatrically-concert activity.

From the point of view of the use in theatrically-concerto activity the objects of legal relationships it costs to divide into: 1) material objects (personal and immobile chattels of theatres, clubs, other establishments, organizations, collectives) and 2) non-material objects : a) services, in thereby agent; b) results of creative activity (musical, audiovisual and other dramatics; them a stage implementation (in complex combination, with treatment or without her); creation of videograms, phonograms; programs (transmissions) of organizations of broadcasting); c) property and d) private unproperty. The last two sub-groups belong to the authors, performers, producers of phonograms, videograms, broadcasting programs (transmissions). Belonging to them: services; results of intellectual, creative activity; property and personal unproperty rights. These objects mainly have non-material character.

Key words: theatrical activity, concert activity, theatrical and concert services, object of legal relations, tangible and intangible objects. 